Street Criers 



\title{
Street Criers
}

\section{A Cultural History of Chinese Beggars}

\author{
HANCHAO LU
}

Stanford University Press

Stanford, California 2005 


\section{Stanford University Press}

Stanford, California

(C) 2005 by the Board of Trustees of the Leland Stanford Junior University. All rights reserved.

No part of this book may be reproduced or transmitted in any form or by any means, electronic or mechanical, including photocopying and recording, or in any information storage or retrieval system without the prior written permission of Stanford University Press.

\section{Library of Congress Cataloging-in-Publication Data}

$\mathrm{Lu}$, Hanchao.

Street criers : a cultural history of Chinese beggars / Hanchao Lu.

p. $\mathrm{cm}$.

Includes bibliographical references and index.

ISBN 0-8047-5148-X (cloth : alk. paper)

I. Beggars-China. 2. Beggars-China-History-igth century.

3. Beggars-China-History-2oth century. 4. China-Social conditionsIgth century. 5. China-Social conditions-2oth century. I. Title: Cultural history of Chinese beggars. II. Title.

HV46IO.A4L 792005

$305.5^{\prime} 69^{\prime} 095 \mathrm{I}-\mathrm{dc22}$

2005009127

Original Printing 2005

Typeset by G\&S Book Services in I0.5/12.5 Bembo 
For Linlin, Frederic, and Jeffrey 
